\title{
Social and Philosophic Aspects of Regional Sustainability in the Global World
}

\author{
Tatiana V. Larionova* \\ Siberian Federal University \\ 79 Svobodny, Krasnoyarsk, 660041, Russia
}

Received 22.01.2015, received in revised form 29.01.2015, accepted 06.04.2015

The article studies the problems connected with peculiarities of the regional sustainability establishment regarding social and economic issues. The author analyzes social and philosophical peculiarities of regional sustainability system, especially important in the conditions of globalization, which has been significantly transforming regional economics. The article demonstrates that regional sustainability in Russia has its own specifics and may become an efficient alternative to negative globalization tendencies of the modern world.

Globalization as a natural process of nations' approximation is based on system sustainability, which supposes sustainability of separate structural units especially well observed during the research of regional social institutes.

In our opinion, the concept of "sustainable development" is mainly social and can be defined by two of its main features: anthropocentric and biosphere-centric. In a general sense, the anthropocentric sign is understood as the survival of humanity and the ability (possibility) of its further ongoing (stable) long continuous development for our descendants to have the same opportunities as the current generation to meet their needs in natural conditions and ecological environment of the Earth and space.

Sustainable development refers to a form of human development when the needs of the present generations are met without doing harm for future generations. Sustainable regional development is a balanced development based on historical traditions and mentality of a particular self-sufficient social unit, thereby providing a continuous, not only socio-economic but also spiritual progress of the society in harmony with others.

The study of peculiarities of regional sustainability in the global world supposes implementation of dialectic principles. During the analysis of regionalization, the fact that globalization of politics is expressed in the appeal to the public point of view, is not taken into consideration, while the public point of view is often a subject of different kind of manipulations. The necessity of the regional approach is also explained by the fact that true democracy is not unification and not forced similarity, but the unity in variety, community of the different. According to this approach, the empirically present form of democracy cannot be something single valued.

In the meantime, the author highlights that regionalism is not chaotic self-determination of social groups. They develop their own rules. Unfortunately, the modern situation in the society contributes more to the immersion of crowds than to the creative development of the personality. Our consumer civilization generates a threat to the total depersonalization and dehumanization of a person.

According to the author, the conception of regionalization obtains specific clarity and intensity in the works of the scholars, who connect real globalization processes with the information stage of the modern research and technology revolution and its real impact on the development of the world

(c) Siberian Federal University. All rights reserved

* Corresponding author E-mail address: berkalleta@mail.ru 
economy. Herewith, the modern stage of regionalization similar to internationalization can be called transnationalization, but overbuilt, newer and higher sphere of human historical existence.

Regional sustainability is closely connected with solving global problems, which even though expanding to the planetary size, at the same time are quite local. For example, the notion of environmental activity in the aspect of global studies demonstrates new ultimate content in the planetary scale. Such are the activities in relation to any global problems, as they affect the vital interests of all the humankind and every single person, even if they do not realize it. The solution of global problems and elimination of globalization negative effects require international cooperation and consolidation of the world community.

The growing interdependence of individual countries and regions due to globalization adds new aspects to the concept of "national and international security". It is quite natural that this historical concept has a strong national connotation, nevertheless there is an overall tendency, which characterizes the entire world community. In particular, the number of external factors affecting the stable functioning of society has been constantly increasing. The state of international security increasingly affects the national security, so the maintenance of stability at the global level, formation of such international mechanisms that would ensure balanced and sustainable development, have become one of the main concerns of regional communities.

The author concludes that the real prospects for sustainable global-regional world order are associated with the dialectical approach to contemporary international processes. Sustainability of the regions is provided by inability of brining diverse social life to a common socio-cultural type determined by its own methods of production and reproduction of social life. The crisis of the ideology of globalism is a natural phenomenon, while it is based on disregard for history, mentality and traditions of a great part of the humankind, because the basis of their policy is the consumer principle of development.

Keywords: region, globalization, regional sustainability, social and economic tendencies, sustainable development.

Research area: philosophy.

Globalization as a natural process of nations' approximation is based on system sustainability, which supposes sustainability of separate structural units especially well observed during the research of regional social institutes.

In our opinion, the concept of "sustainable development" is mainly social and can be defined by two of its main features: anthropocentric and biosphere-centric. In a general sense, the anthropocentric sign is understood as the survival of humanity and the ability (possibility) of its further ongoing (stable) long continuous development for our descendants to have the same opportunities as the current generation to meet their needs in natural conditions and ecological environment of the Earth and space.

Sustainable development refers to a form of human development when the needs of the present generations are met without doing harm for future generations. Sustainable regional development is a balanced development based on historical traditions and mentality of a particular self-sufficient social unit, thereby providing a continuous, not only socio-economic but also spiritual progress of the society in harmony with others.

The problem of sustainability is actualized by the fact that in the opinion of modern European scientists the nation is not the basis of the state and its sovereignty anymore, it is treated as "a vessel for implementation of civil freedom" and the presumption of the uniqueness of the statelegal system should leave the front of the stage of history: "the national state thinking and actions should be denationalized" [1]. Herewith, they argue that the rights and freedoms of citizens are the effective universal basis of civic identity in the modern globalizing world. 
Investigation of the features of social sustainability in the global world involves implementation of dialectic principles. Dialectics has become the basis of the dialectical system of theorizing, which includes all scientific theories exploring the world from the perspective of the principle of the unity of being. The dialectic system of theorizing was taken as the basis in the Russian science and philosophy. But while maintaining the importance of the subject in social theory, one should bear in mind the close intertwining of human subjectivity and its neutralization in real life [8, p. 84].

In the analysis of regionalization, the fact that globalization of politics is expressed in the appeal to public opinion, which is itself the subject of all sorts of acts of manipulation, is often neglected. Politics becomes speculative and gets separated from the protection of the nation's basis and interests. The Internet should be also viewed as one of manifestations of globalization and the connection between them should be outlined. The danger is that these forms begin to resonate and "heat up" the world to the point of incandescence. Technological and ecological disasters, economic and financial crises, acts of terrorism and, finally, computer viruses, which many of us still treat too absentmindedly, are all dangerous features. Meanwhile, these are the phenomena of the same order and their harmfulness also increases rapidly in the state of resonance [6, pp. 5-7].

The necessity of the regional approach is also explained by the fact that true democracy is not unification and not forced similarity, but the unity in variety, community of the different. According to this approach, the empirically present form of democracy cannot be something single valued. For optimum arrangement of socio-political system of a particular society in a particular country, this system should be based on the culture of this country and this society. Democracy cannot be copied and "exported".
However, the idea that localization is a reversed, dark side of globalization, appears quite right. Local people, in the opinion of I. Kudashova, remain local forever [7, p. 188].

In the meantime, it is important to emphasize that regionalism is not chaotic self-determination of social groups. They develop their own rules. Unfortunately, the modern situation in the society contributes more to the immersion of crowds than to the creative development of the personality. Our consumer civilization generates a threat to the total depersonalization and dehumanization of a person.

Understanding the origins of the regional approach to the modern world configuration is largely due to the fact that "... the issue of the benefits' distribution is one the most burning issues of globalization raised not only by representatives of the countries with the lowlevel development, but also by representatives of highly developed countries, which understand the perspective and look at things from a strategic point of view. A well-known Russian economist O. Bogomolov said that previous financial crises are the consequence of globalization and liberalization [3, p. 9]. In this regard, the development of the idea of regionalization, as the optimal arrangement of the future world order, is contributed by further development of the idea of civilization. For example, the idea of the polarity of civilization is the central one in the research of prominent European philosophers, such as O. Spengler and K. Jaspers. In his famous work, "The Meaning and Purpose of History", Jaspers emphasizes, "in its various modifications, the original polarity has retained its vitality through the centuries ... The Greeks and Persians, the division of the Roman Empire into Western and Eastern, Western and Eastern Christianity, the Western world and Islam, Europe and Asia are the successive elements of this contradiction" [9, p. 116]. 
An important aspect of analyzing peculiarities of sustainability at the regional level involves considering the fact that the global studies deal with non-linear open world, including the Cosmos. Therefore, the structure of laws should contain all aspects of sustainable development and co-evolution of man and nature to more or less significant extent. Their content should include objective and subjective elements, and the objective global process itself and the idea of it, its implementation in the society. Globalization laws are the laws-concepts, the laws where the natural, physical, geographical and biographical are fused with social, economic, spiritual, etc. The conception of regionalization obtains specific clarity and intensity in the works of the scholars, who connect real globalization processes with the information stage of the modern research and technology revolution and its real impact on the development of the world economy, finance, telecommunications and transportation systems, science, transforming the existence of the humankind with an increasing speed. Herewith, the current stage of regionalization similar to internationalization can be called transnationalization, but overbuilt, newer and higher sphere of human historical existence.

To understand the importance of developing the concept of regional sustainability, it is crucial to recognize the characteristics of the system in a particular region, which are expressed in the interrelation and balance of economics, environment and social sphere, i.e. solving social and economic problems combined with preservation of a favourable environment and natural resources potential. Moreover, it is important to consider that the neoliberal globalists had been constantly stressing the inevitability of globalization and in the model that they presented. Confronting neoliberal globalization was announced meaningless. For a more or less painless entry into the globalization processes, countries and their nations were supposed to follow the next recipe: to organize every possible liberalization of trade and prices; to implement strictfiscal policy; to deregulatebusiness activities; to reduce the economic activity of the state in every possible way; to privatize state property; to stabilize the financial system, primarily due to the expansion of exports; to balance the state budget reducing its expenditure items to the limit, etc. This set of requirements was popularly known as the Washington Consensus, and played a significant role in the development of the world economy in the last quarter of the $20^{\text {th }}$ century. During the short period, large new areas and spheres of human activity had been involved into commodity-money relations, the proportions and balance of power among nations, corporations, corporations and countries - economic entities had been altered, the relation between politics and the economy, finance and industry, competition and scientific and technological progress had changed.

Regional sustainability is closely related to solving global challenges, which though expanding to planetary dimensions, at the same time have certain locality. Thus, the concept of environmental performance in the aspect of global studies expresses new ultimate content appearing on the planetary scale. This is the way to address any global problems, as it affects the vital interests of the whole humankind and each particular person, even if they do not realize it. Moreover, the solution of global problems and the elimination of the negative aspects of globalization require international cooperation and consolidation of the world community.

It is possible to create an adequate model of sustainable regional development if we consider any region formed during the past centuries as a system. According to the theory of systems, the existence of any system integrity is due to the contradictions between its constituent elements, 
and the system itself is the way and the form of the resolution of these conflicts. In terms of rare ethnic and linguistic diversity, which is observed in the Caucasus, the problem of communication and interaction, of course, inevitably arose as an issue of life and death "in relation to each local social group (ethnic group, subethnic group) [2, p. 261].

The regional approach helps to solve another problem, which is related to the fact that the outcome of the industrial age was the division of the known Ecumene into the "black" and "gold" billions, and the latter, accounting for about onefifth of the world's population, consumes more than $2 / 3$ of the resources of all kinds. It is clear that such "distribution" is perceived by the majority of the world population as extremely "unfair": in any case, it can only supported by the superiority in power. Formally, "developed countries" retain this advantage. But the military power of Europe is impaired by low passionarity of the "privileged people". Moreover, the dominance of the "golden billion" is undermined by secondary effects of globalization. Buchanan rightly notes that "all the countries have the same choice - either national sovereignty or the destruction of the nation and the state. And it is not the case to be spineless". For the implementation of this programme it is necessary "to oppose the additional funding of the World Bank and the IMF. These organizations have loaned hundreds of billions of dollars of American taxpayers to other countries, and under the conditions for which most bankers go to jail. Thus, the IMF has received powerful leverage of influence on the credited countries and forces them to obey the dictate of the global elite. This leverage should be removed, of course [4, p. 330331].

Supporters of the regional approach agree with A. Dugin, who reasonably said: "Today all responsible people should understand that the adoption of the mondialistic model is neither more nor less than complete and final destruction of the uniqueness, historical identity of their states and nations, the end of their nation's history" [5]. In particular, regionalism enables us to understand that any attempts of forced intervention in complex, multifactorial conflicts would be counterproductive boomeranging on the interests of the initiators of these actions. The resonant wave can take various contours: international terrorism, increasing of migration flows to industrialized countries, intensification of trade of arms and drugs, etc.

In the global social space, redistribution of identities is artificially imposed leading to the formation of new conditions of the division of societies. Fragmentation of national communities, regional division of labour, a shift in priorities, ideological struggle and the expansion of certain types of cultural values lead to the situation when we have more and more opportunities for the market. In fact, the person is put in the conditions of a kind of market of identities, with their advertising and anti-advertising, denying their right to possess a sustainable set of the latter. Such a market providing, on the one hand, "free choice" idealized and promoted by the individualistic ideology, on the other hand, requires a high price to be paid in terms of unfair competition.

The growing interdependence of particular countries and regions in the course of globalization brings new aspects to the concept of "national and international security". It is quite natural that this historical concept has a strong national connotation, nevertheless there is a general tendency, which characterizes the entire world community. In particular, the number of external factors affecting the stable functioning of the society has been increasing. The state of the international security has been increasingly affecting the national security, so maintenance of sustainability at the global level, contribution to the formation of such international mechanisms 
that would ensure balanced and sustainable development, has become one of the main concerns of regional communities.

The growing interdependence in the sphere of international relations resulting from globalization brings new aspects to the concept of "national and international security". It is quite natural that this historical concept has a strong national connotation, nevertheless there is a general tendency, which characterizes the entire world community. In particular, the number of external factors affecting the stable functioning of the society has been increasing. The state of the international security has been increasingly affecting the national security, so maintenance of sustainability at the global level, contribution to the formation of such international mechanisms that would ensure balanced and sustainable development, has become one of the main concerns of regional communities. In this regard, the historical knowledge plays a fundamental role. Organization of the historical knowledge based on logical principles has reflected its dynamics at the macro level and has been adapted for the institutional functioning in the society. However, such organization demonstrates its limitation in the implementation of scientific research and the expression of the dynamics of knowledge providing updates of its basics" [10, p. 230]. The fact that the presence of the properly interpreted historical experience of other nations largely facilitates broadcasting of the decision to the masses by the elite responsible for making the decision. In this case, the need for theoretical justification of the chosen path is significantly reduced, sometimes it is enough to provide a reference to the common sense of the society and a good positive example [11, p. 226].

Therefore, the real prospects for sustainable global-regional world order are associated with the dialectical approach to contemporary international processes. Sustainability of the regions is provided by inability of brining diverse social life to a common socio-cultural type determined by its own methods of production and reproduction of social life. The crisis of the ideology of globalism is a natural phenomenon, while it is based on disregard for history, mentality and traditions of a great part of the humankind, because the basis of their policy is the consumer principle of development.

\section{References}

1. Altermatt, U. Etnonatsionalizm v Evrope [Ethnic Nationalism in Europe]. Translated from German. Moscow, 2000.

2. Akhestova, M.Z. K kul'turno-filosofskim aspektam identifikatsii kavkazskoi lokal'noi tsivilizatsii [To the Cultural and Philosophic Aspects of Identity of the Caucasian Local Civilization] // Science and Theory Journal "Nauchnye problemy gumanitarnykh issledovanii" ["Research Challenges in the Humanities"] Issue 5. Pyatigorsk, 2011. P. 261.

3. Bogomolov, O. Globalizatsiia kak sterzhnevaia problema griadushchego mirovogo razvitiia [Globalization as the Key Problem of the Future World Development] "Round-table Discussion" in the Editor's Office of "Mezhdunarodnaia zhizn" [International Life] // Mezhdunarodnaia zhizn' [International Life]. 2000. No.11. P. 9.

4. Buchanan, P.J. The Death of the West. Translated from English. Moscow: Izdatel'stvo AST, LLC; Saint Petersburg: Terra Fantastica, 2003. pp. 330-331.

5. Dugin, A. Osnovy geopolitiki. Geopoliticheskoe budushchee Rossii [Basics of Geopolitics. Geopolitical Future of Russia]. Moscow: Arktogeia, 1997. 
6. Iaspeks K. Smysl i naznachenie istorii [Meaning and Purpose of History] / K. Iaspels; INION. Moscow, 1991. Pp. 115-116.

7. Iatsenko M.P. Globalizatsiia kak forma istoricheskogo protsessa $i$ aksiologiia istorii [Globalization as a Form of the Historical Process and Axiology of History] // Nauchno-teoreticheskie problemy gumanitarnykh issledovanii [Scientific and Theoretical Problems of Research in the Humanities]. Scientific and Theoretical Journal. Issue No. 9. Pyatigorsk, 2010. P. 230.

8. Iatsenko M.P. Istoricheskie aspekty globalizatsii kak upravliaemogo protsessa [Historical Aspects of Globalization as a Controlled Process] // Vestnik Orlovskogo gosudarstvennogo universiteta [Bulletin of Oryol State University] Series: New Research in the Humanities. 2011. No. 5(19). P. 226.

9. Krupnin G.N. Otchuzhdenie cheloveka v perspective globalizatsii mira [Alienation of the Human in the Perspective of the World Globalization]. Collection of Articles. Issue 1 / Edited by Markov B.V., Solonin Iu.N., Partsvaniy V.V. Saint Petersburg: Petropolis, 2001. Pp. 5-7.

10. Kudashova I.V. Krisis politiki v protsesse globalizatsii i lokalizatsii [Crisis of Politics in the Process of Globalization and Localization] // Teoriia i istoriia [Theory and History]. 2004. No. 3. P. 188 .

11. Mureiko L.V. Massovoe soznanie: o spetsifike sub'ekta massmedia [Mass Consciousness: the Specificity of the Mass Media Subject] // Izvestiia Rossiiskogo gosudarstvennogo pedagogicheskogo universiteta im. A.I. Gertsena [Bulletin of Herzen Russian State Pedagogical University] No. 111: Scientific Journal. Saint Petersburg, 2009. P. 84.

\section{Социально-философские аспекты региональной устойчивости в глобальном мире}

Т.В. Ларионова

Сибирский федеральный университет Россия, 660041, Красноярск, пр. Свободныий, 79

\footnotetext{
В статье исследуются проблемы, связанные с особенностями становления региональной устойчивости в сочиально-экономическом плане. Автор проводит сочиильно-философский анализ особенностей выработки системы устойчивости региона. Это приобретает особую значимость в условиях глобализации, которая во многом трансформирует региональную экономику. Как показано в статье, региональная устойчивость имеет свою специфику в России и может стать действенной альтернативой негативным глобализационным тенденциям современности.

Глобализация как естественный процесс сближения наций базируется на системной устойчивости, которая подразумевает устойчивость отдельных структурных единии, что особо проявляется на основе исследования региональных социальных институтов.

Понятие «устойчивое развитие», на наш взгляд, имеет принципиальный социоприродный характер и может быть определено с помощью двух своих основных признаков антропоцентрического и биосфероцентрического. Под антропоцентрическим признаком в широком смысле понимается выживание человечества и способность (возможность) его дальнейшего непрекращающегося (устойчивого), непрерывно долгого развития, чтобы наши потомки имели бы не меньше возможностей по сравнению с настоящими поколениями по
} 
удовлетворению своих потребностей в природных условиях и экологических условиях Земли и космоса.

Под устойчивым развитием понимают такую форму развития человечества, при которой удовлетворение потребностей настоящих поколений осуществляется без ущерба для будущих поколений. Устойчивое региональное развитие - это сбалансированное, базирующееся на исторических традициях и менталитете развитие конкретной самодостаточной социальной единицы, в результате чего обеспечивается непрерывный не только сочиально-экономический, но и духовный прогресс этого общества в гармонии с другими.

Исследование особенностей региональной устойчивости в глобальном мире предполагает использование диалектических приниипов. При анализе регионализации часто не учитывают тот факт, что глобализачия политики выражается в апелляции к общественному мнению, которое само выступает предметом разного рода манипуляиии. Необходимость регионального подхода объясняется еще и тем, что подлинная демократия - это не унификаиия и не насильственная одинаковость, это единство в многообразии, это содружество различного. Согласно такому подходу эмпирически наличная форма демократии не может являться чемто однозначнымм.

Вместе с тем автор подчеркивает, что регионализм - это не хаотическое самоопределение соииумов. Здесь срабатывают свои законы. К сожалению, современная ситуация в обществе более способствует возникновению толп, нежели творческому развитию личности. Наша потребительская цивилизация образует угрозу тотальной деперсонализации и дегуманизации человека.

По мнению автора, особую научную четкость и содержательность конщепџия регионализации приобретает в трудах тех ученых, которые связывают реальные глобализачионные процессы с информационным этапом современной научно-технической революиии и ее реальнымм влиянием на развитие мировой экономики. В этом плане современный этап регионализации может быть по аналогии с интернационализацией назван транснационализацией, но надстраивающейся над нею, более новой и высокой сферой человеческого исторического бытия.

Региональная устойчивость тесно связана с решением глобальных проблем, которые, расширяясь до планетарных размеров, в то же время имеют определенную локальность. Например, понятие экологической деятельности в аспекте глобалистики выражает новое предельное содержание, проявляясь в планетарных масштабах. Такова деятельность по решению любой глобальной проблемы, поскольку затрагивает жизненно важные интересы всего человечества и любого человека в отдельности, даже если он этого не осознает. Причем решение глобальных проблем и устранение негативов глобализации требует международного сотрудничества и консолидации всего мирового сообщества.

Возрастающая в результате глобализации взаимозависимость отдельных стран и регионов привносит новые аспекты в понятие «национальная и международная безопасность». Вполне естественно, что это историческое понятие имеет ярко выраженную национальную окраску, однако наблюдается общая тенденция, которая характеризует все мировое сообщество. В частности, увеличивается число внешних факторов, влияющих на стабильное функиионирование общества. Состояние международной безопасности все в большей мере оказывает влияние на обеспечение национальной безопасности, поэтому поддержание стабильности на глобальном уровне, содействие формированию таких международных механизмов, которые обеспечивали бы сбалансированное и устойчивое развитие, становится одной из главных забот региональных сообществ.

Автор приходит к выводу, что реальные перспективы устойчивого глобально-регионального мироустройства, что связано с диалектическим подходом к современным международным прочессам. Устойчивость регионов обеспечивается невозможностью сведения всей разнообразной сочиальной жизни к единому сочиокультурному типу, обусловленному собственными способами производства и воспроизводства общественной жизни, Кризис идеологии глобализма выступает закономерным явлением, поскольку в его основе находится 
пренебрежение историей, менталитетом и традициями огромной части человечества, потому что в основе их политики находится потребительский принцип развития.

Ключевые слова: регион, глобализация, региональная устойчивость, социально-экономические тенденции, устойчивое развитие.

Научная специальность: 09.00.00 - философские науки. 